\title{
Influences on the work engagement of secondary school teachers in rural Kwazulu-Natal
}

\author{
GDEHALOO AND S SCHULZE ${ }^{2}$
}

\begin{abstract}
The aim of this research was to investigate the influence of job resources and job demands on the work engagement of secondary school teachers in the Illembe district of KwaZulu-Natal. A previously developed model for work engagement was used as conceptual framework. In the empirical investigation the authors used a mixed-method, explanatory research design. In the quantitative phase 100 teachers from five schools completed a self-constructed questionnaire which allowed for hypotheses testing. This was followed by 16 interviews with teachers from the same sample. The study revealed that the teachers exhibited low levels of work engagement. This was related to inadequate job resources and excessive job demands. The teachers were particularly displeased with their remuneration packages. However, teachers of different genders, cultures, levels of experience and educational qualifications differed in their perceptions. Through the interview data the authors gained a deeper understanding of how the above-mentioned impacted on work engagement. The study is significant for illuminating current factors that managers should consider to improve the work engagement of teachers.
\end{abstract}

Keywords: Work engagement; job resources; job demands; motivation; job satisfaction; mixed-methods.

\section{Introduction}

Work engagement is a relatively new concept that refers to a state that demonstrates vigour, dedication and absorption in the job (Bakker \& Demerouti 2008:209). Bakker and Schaufeli $(2008: 147)$ recommended that work engagement in organisations be put on the research

1. Gunram Dehaloo is a DEd student, UNISA, PO Box 392, Pretoria.

2. Salomé Schulze, (corresponding author) is attached to the Department of Psychology Education, UNISA, PO Box 392, Pretoria. Tel. 012804 6113, Fax: 086 6421 640, schuls@unisa.ac.za. 
agenda. In South Africa such investigations are limited, as shown by an electronic search. Four examples were found which were conducted with police officers (Rothmann \& Storm 2003); female academics (Bezuidenhout \& Cilliers 2012); employees in a government and a manufacturing organisation (Stander \& Rothmann 2010) and with church ministers (Buys \& Rothmann 2010). Apparently no South African study investigated the work engagement of teachers.

Research on the work engagement of South African teachers is particularly needed since studies revealed several problem areas that could influence their work engagement. For example, teachers were unsatisfied with poor salaries, heavy workloads, few opportunities for career advancements, and unworkable policies (Kallaway 2007:30; Maniram 2007:4; Roper 2007:10). Added to the before-mentioned were uninvolved parents, poor student discipline and continuous changes in the education system (Schulze \& Steyn 2007:691). Many schools were also characterised by poor race relations, unsatisfactory appointment and promotion processes and poor relations between management and staff (Dehaloo 2008). All of these factors could inhibit the work engagement of the teachers.

Work engagement or lack thereof translates into behaviour. Many South African teachers quit teaching (in Maniram 2007:4). Students who observed de-motivated teachers also became unenthusiastic (Atkinson 2000:45-47; Kelehear 2004:32; Rowley in Steyn 2002:83).

In contrast to unmotivated teachers, engaged employees have high energy and self-efficacy that help them to exercise influence over events that affect their lives. They are creative and productive (Bakker \& Demerouti 2008:209). The research question that motivated this study was therefore: How do selected factors impact on the work engagement of secondary school teachers in the Ilembe District of KwaZulu-Natal? The Illembe district is a rural area and therefore experiences particular difficulties, as is indicated further in the article.

\section{Conceptual framework: a model of work engagement}

Work engagement is defined as "a positive, fulfilling, work-related state of mind that is characterized by vigor, dedication, and absorption" (Schaufeli in Bakker \& Demerouti 2008:209). Engagement has physical, emotional and cognitive components.

Bakker and Demerouti (2008:218) designed a model for work engagement that is useful to managers. Drivers of work engagement are job resources and personal resources. Job resources play an intrinsic motivational role since they foster teachers' learning and development. Job resources can also play an extrinsic motivational role when they are instrumental to achieve work-related goals. Job resources refer to, among others, the physical environment in which teaching takes place, social support, supervisory coaching and performance feedback. Job resources are particularly important when job demands are high. Job demands are related to work pressure, as well as to the emotional, mental and physical demands of the work. Personal resources are intrinsic and relate to the levels of optimism, self-efficacy, resilience and self-esteem of the teacher. As such they are not easy to change.

Job resources and personal resources are inter-related. These resources motivate teachers to a greater or lesser extent for work engagement which, in turn, influences teacher performance. Work engagement affects job resources and personal resources since teachers can perform in such a way that they may improve their job and personal resources. For example, teachers 
who are diligent and creative generate positive feedback and social support from managers and thus enhance their job resources.

By using the above-mentioned model of work engagement as lens, this study's specific aim was to investigate the role of job resources and job demands on the work engagement of secondary school teachers in the Ilembe District of KwaZulu-Natal. There are two reasons why job resources and job demands were selected: firstly, managers have more power to change these factors than to alter teachers' personal resources (e.g. their optimism, selfefficacy, resilience and self-esteem), as mentioned. Secondly, if job resources and demands could be improved, this may enhance the personal resources of the teachers since these two variables are interrelated (Bakker \& Demerouti 2008:217). For example, self-efficacy of teachers (a personal resource), is increased by means of positive feedback from managers (Evans 1989:60; Powell, Bordoloi \& Ryan 2007:105), and positive feedback is an aspect of job resources, as explained.

\section{Job resources of South African teachers}

Several authors (in Ololube 2006:6) maintain that motivation at work is enhanced by psychological rewards which include meaningful and varied work, task autonomy, participatory decision-making, positive feedback, collaboration, administrative support, reasonable workload, adequate resources and pay, and learning opportunities providing challenge and accomplishment. The question is to what extent these factors are present in the school context of the South African teacher.

Teaching in rural areas in South Africa is particularly challenging (Bloch 2010:6; Panday \& Arends 2008:22). These challenges include: a lack of clean water, proper sanitation and basic infrastructure; overcrowding in classrooms; lack of teacher support; student ill-discipline; lack of parental involvement; violence at school; and poor resources (Davids \& Makwabe 2007:1; Guttman 2007:14-15; Karp 2007:5; Mohlala 2010:2). Cohen (2009:7) confirms that teachers in many rural schools work under difficult conditions in comparison to their counterparts in the more affluent areas. For this reason the Department of Health offers its employees scarce skills and rural allowance in contrast to the Department of Education (DoE), (Department of Public Service and Administration 2009).

The socio-economically advantaged schools in urban and suburban areas have lower teacherstudent ratios than rural schools as their economic resources allow for the employment of School Government Body (SGB) paid teachers and teacher aides. By comparison, rural schools struggle with large class sizes of 45 and more students (Phurutse 2005:14; Serrao 2010:4). The Education Roadmap (Development Bank of South Africa 2008:6) identified a major improvement in teacher-student ratios, from 43:1 in 1996 to 32:1 in 2006. However, such figures predominate on paper only, as the geographic location of schools together with their socio-economic standing determine class size and teacher-student ratios.

\section{$4 \quad$ Job demands}

The National Education Policy Act of 1996 identified seven roles for teachers. These were: learning mediator; interpreter and designer of learning programmes and materials; leader, administrator and manager; scholar, researcher and life-long student; assessor; learning area 
and subject specialist and also a community citizen and pastor (Republic of South Africa 2000). Accordingly, teachers often felt that they were counsellors, social workers, managers, examiners and secretaries who were concerned with the performance of students (Schulze \& Steyn 2007:694). Such demands gave rise to role ambiguity and role conflict.

In their dealings with students, South African teachers were confronted with unruly behaviour that impacted negatively on learning and teaching (Samuel 2007:5; Karp 2007:5). Since the banning of corporal punishment in 1996 student discipline was one of the most talked about challenges teachers faced, since many of them were uncertain how to maintain discipline (Marais \& Meier 2010: 41; Mokhele 2006). Students' unruly behaviour was attributable inter alia to lack of student motivation. Unmotivated students were often absent from class, were unconcerned about perceptions about them and displayed disruptive behaviour (Davids \& Makwabe 2007:1; Kyriacou 2001:29; Schulze \& Steyn 2007: 695).

Amidst the above difficulties, South African teachers were evaluated by means of an Integrated Quality Management System (IQMS). Weber (2005:70) highlighted two concerns regarding the IQMS. Firstly, that the system focused exclusively on schools and government employees, viz. teachers. It did not explain by what procedures the national DoE would be made accountable. The idea that the department had the responsibility for providing resources to support learning and teaching (Education and Labour Relations Council 2003:3) was not followed through regarding what would be provided and how it would be done, who would evaluate the adequacy of the resources and the development of human resources. The second concern was that the IQMS marginalised two important groups: students and parents on the one hand, and their representative organisations (the student representative councils and the SGBs) on the other hand.

A World Bank study on secondary education in Africa revealed that for teachers to be effective and competent, they should have curricular (subject) knowledge, pedagogical knowledge (on how to teach), as well as societal knowledge. In addition, teachers required educational resources and expertise in using these resources, an effective curriculum and an environment that was conducive to teaching and learning (De Clerq 2008:8). In the South African context, these factors were absent in many schools. The poor socio-economic backgrounds of many students, the school context, inadequate management and resources, coupled with poor teacher development militated against the use of a single uniform evaluation instrument such as the IQMS (Gallie 2006; Khan, Mfusi \& Gasa 2010:1).

With the above as background, this research focussed on the influence of job resources and job demands on the work engagement of secondary school teachers in the Illembe district of KwaZulu-Natal. To this end, the next section addresses the research design and data collection. Thereafter the results are discussed and conclusions are drawn.

\section{Method}

This study used a mixed-method explanatory research design where a quantitative phase was followed by a qualitative phase. This approach permitted the authors to identify trends and explore them further to obtain insight into the topic under investigation (Cresswell 2003:216; McMillan \& Schumacher 2010:396). Since the focus was on job resources and job demands of teachers in particular, the authors designed their own instrument (a questionnaire) for the 
quantitative phase. The researchers were also more interested in the quality of work engagement than a numeric figure and this required a qualitative approach.

In the quantitative phase a structured questionnaire, which was pilot-tested, was used to survey teachers. The first section of the questionnaire collected demographic data while the rest related to the job resources and job demands of the teachers. They were requested to respond to a three point Likert scale, ranging from disagree to agree. In the final section of the questionnaire some qualitative data were obtained by means of open-ended questions that required the teachers to describe what motivated or de-motivated them.

The authors ensured content validity and face validity through expert opinion. To determine the instrument's reliabilities, the Cronbach alphas were calculated for the various constructs of the questionnaire - these were all above 0,7 which is acceptable (McMillan \& Schumacher 2010: 184).

The quantitative data was interpreted by means of descriptive statistics. The following hypotheses were also tested: There is a significant difference between the perceptions of different groups of teachers of job resources and job demands. In line with the conceptual framework, the job resources included physical and financial contexts, performance feedback, social support and coaching. The groups differed with regard to gender, culture, levels of experience, and qualifications. The hypotheses were tested by means of t-tests and Analysis of Variance (ANOVAs).

The study population was all the teachers of the Ilembe district of KwaZulu-Natal. Five schools in this district were purposefully selected because it was a rural area, conveniently situated and accessible. A sample of 100 teachers was randomly selected for participation. Questionnaires were hand-delivered and collected after completion.

In the qualitative phase 16 teachers (at least three per school), were purposefully selected from the above-mentioned sample to ensure inclusion of male (M), female (F), Black (B) and Indian (I) teachers with different years of experience and educational level. (There were no other cultural groups employed at the schools.) The teachers were interviewed to gain an indepth understanding of the results of the quantitative phase.

The authors ensured trustworthiness of the qualitative data by conducting the interviews in the natural settings of the teachers that reflected the reality of their work situations, using a tape-recorder during the interviews and transcribing these verbatim. The qualitative data was analysed by the constant comparative method (McMillan \& Schumacher 2012:377).

Ethical issues were adhered to. For example, the authors obtained permission for the research from all relevant stakeholders, and ensured the anonymity and confidentiality of the respondents.

\section{Results}

Table 1 presents the biographical information of the teachers who completed the questionnaires. 
Table 1: Biographical data of the respondents

\begin{tabular}{|c|c|}
\hline Variable & Percentage \\
\hline \multicolumn{2}{|c|}{ Gender } \\
\hline Male & 41 \\
\hline Female & 59 \\
\hline \multicolumn{2}{|c|}{ Age on 30 April 2011: } \\
\hline 26 years and younger & 14 \\
\hline Between 27-39 years & 39 \\
\hline Between $40-54$ years & 37 \\
\hline 55 years and older & 9 \\
\hline \multicolumn{2}{|c|}{ Race: } \\
\hline African & 40 \\
\hline Indian & 60 \\
\hline \multicolumn{2}{|c|}{ Teaching experience: } \\
\hline Less than 6 years & 20 \\
\hline Between 6 and 15 years & 41 \\
\hline Between 16 and 25 years & 20 \\
\hline 26 years and longer & 19 \\
\hline \multicolumn{2}{|c|}{ Current post: } \\
\hline Teacher level 1 & 86 \\
\hline Department head & 11 \\
\hline Deputy principal & 2 \\
\hline Principal & 1 \\
\hline \multicolumn{2}{|c|}{ Highest teaching qualification: } \\
\hline Teaching certificate & 9 \\
\hline Teaching diploma & 32 \\
\hline B degree & 41 \\
\hline Hons degree & 14 \\
\hline M Ed degree & 3 \\
\hline
\end{tabular}

Table 1 shows that the majority (59) of the 100 respondents were female. Most of them (60) were Indian and the remaining 40 were Black. Age-wise, the majority (39 and 37 respectively) of respondents were between the ages of 27 and 39 years, or 40 and 54 years. In terms of teaching experience, 41 teachers (the biggest group) had between six and 15 years experience. Of the teachers, 86 were at level 1 only. In terms of teaching qualifications, the biggest group of 37 teachers held bachelor's degrees, while 32 had teaching diplomas.

The perceptions of the teachers of their job resources and job demands are illustrated in the four tables that follow. (Since there were 100 respondents, frequencies and percentages are identical and thus not separately provided.)

\subsection{Job resources}

\subsubsection{Physical and financial environment}

In Table 2, the teachers' views of their physical and financial contexts are provided. 
Table 2: $\quad$ Perceptions of the physical and financial working context

\begin{tabular}{|l|c|c|c|}
\hline \multicolumn{1}{|c|}{ Item } & $\begin{array}{c}\text { Disagree } \\
\%\end{array}$ & $\begin{array}{c}\text { Neutral } \\
\%\end{array}$ & $\begin{array}{c}\text { Agree } \\
\%\end{array}$ \\
\hline $\begin{array}{l}\text { I teach students who come from financially secure } \\
\text { families }\end{array}$ & 71 & 17 & 12 \\
\hline My school is well-resourced & 59 & 26 & 14 \\
\hline $\begin{array}{l}\text { The DoE is generally quick to deliver resources to my } \\
\text { school. }\end{array}$ & 65 & 27 & 6 \\
\hline Overall, my school has a good infrastructure. & 35 & 25 & 40 \\
\hline I have an acceptable number of students in my class. & 51 & 14 & 34 \\
\hline In my view my salary keeps up with inflation. & 80 & 11 & 9 \\
\hline I feel that all teachers are paid fairly & 83 & 11 & 4 \\
\hline $\begin{array}{l}\text { Student involvement in school life is enhanced by their } \\
\text { financial environment. }\end{array}$ & 45 & 28 & 27 \\
\hline
\end{tabular}

The most important observations in Table 2 include the fact that the majority of the teachers (59\% and 65\% respectively) disagreed that their schools were well resourced or that the DoE delivered resources on time. The most positive response was with regards to infrastructure: $40 \%$ of the teachers agreed that their schools had good infrastructure.

Regarding financial issues, it was clear that most of the teachers thought that their students came from financially challenged homes; $80 \%$ and more teachers were also dissatisfied with their own salaries.

When hypotheses were tested by means of ANOVA, and when post-hoc t-tests were performed, it was determined that the teachers' level of experience and qualifications influenced their perceptions of the above-mentioned issues. Teachers with 26 and more years of experience were significantly more satisfied (on the 5\%-level) with their physical and financial contexts than the less experienced teachers (Means: $<6=1,64818 ; 6-15=1,72943$; 16-25:1,65455; 26+=2000; F-ration=3,4831; significance=0,0188). Regarding qualifications, teachers with bachelor's or with master's degrees were significantly more satisfied (on the 5\%level) with their physical and financial contexts than teachers with certificates. Of the whole group, teachers with certificates only were least satisfied with their physical environments (Means: 1,85670 for B degree and 1,84848 for $\mathrm{M}$ degree versus 1,45455 for a certificate; $\mathrm{F}=2,9004$; significance $=0,0266$ ).

The qualitative data confirmed the quantitative data. Teachers attested to the fact that modern resources such as computers, projectors, television sets and DVD recorders and players, and other technologically relevant equipment that have revolutionised present day teaching and learning, were not available at the school. This lent credence to the argument that teachers in the schools had unequal opportunities of service delivery as opposed to their counterparts in more affluent areas. In addition to that, the schools were often in states of neglect. One teacher stated:

The infrastructure at the school leaves much to be desired. Classrooms are in a deplorable state... furniture is broken, windows damaged. Some windows don't open. During hot days we suffer. There are no air cons, no fans like in some of the other schools. Our toilets have been repaired on several occasions... but students just damage them. There is a need for more toilets to be provided for our pupils. (IM) 
During the interviews, teachers also expressed discontent with their salary packages, which they considered as unrelated to the amount of work they did. Dissatisfaction with salaries focussed on discrepancies between neonates and experienced teachers; subordinates earning higher salaries than their superiors; freezing of capped leave; and lack of tangible salary adjustments for improved academic qualifications. Examples include:

Teacher salaries are not in keeping with inflation ... it is a bit unfair. It is based on qualifications only. Years of service are not taken into account. Looking at entry level teachers earning more than serving teachers ... this tells you that the Department doesn't care, doesn't look at skills and experience but at qualifications only... this impacts on experienced teachers who leave for the private sector, or get self employed. (IF)

\subsubsection{Performance feedback}

Table 3 illustrates teachers' views of the feedback they received on their performances.

Table 3: Perceptions of performance feedback

\begin{tabular}{|l|c|c|c|}
\hline \multicolumn{1}{|c|}{ Item } & $\begin{array}{c}\text { Disagree } \\
\%\end{array}$ & $\begin{array}{c}\text { Neutral } \\
\%\end{array}$ & $\begin{array}{c}\text { Agree } \\
\%\end{array}$ \\
\hline $\begin{array}{l}\text { Recognition (e.g. praise) motivates teachers at my } \\
\text { school to perform well. }\end{array}$ & 22 & 27 & 49 \\
\hline $\begin{array}{l}\text { Teachers at my school are satisfied with the DoE's } \\
\text { initiatives at rewarding teachers for good student } \\
\text { results. }\end{array}$ & 47 & 26 & 27 \\
\hline $\begin{array}{l}\text { The DoE's National Teaching Awards Programme } \\
\text { is an effective instrument to recognise best practice } \\
\text { in education. }\end{array}$ & 56 & 26 & 18 \\
\hline $\begin{array}{l}\text { The long-term service awards (for 20 or 30 year } \\
\text { service) should be paid out from teachers' capped } \\
\text { leave. }\end{array}$ & 60 & 19 & 21 \\
\hline $\begin{array}{l}\text { Teachers on my staff are happy with the payment of } \\
\text { once-off cash bonuses in recognition of improvement } \\
\text { in educational qualifications. }\end{array}$ & 66 & 22 & 12 \\
\hline $\begin{array}{l}\text { The DoE's Laptop Initiative would empower } \\
\text { teachers on my staff to improve their classroom } \\
\text { practice. }\end{array}$ & 35 & 19 & 46 \\
\hline
\end{tabular}

Table 3 shows that, with regard to recognition and performance feedback, percentages of 49 and 46 show that teachers are motivated by recognition such as praise. For some teachers $(46 \%)$, reward could be in the form of computer laptops. However, most teachers $(60 \%$ and $66 \%$ respectively) show dissatisfaction with rewarding teachers by paying out long-term service awards from capped leave or with once-off cash bonuses for improving their qualifications.

The above issues were confirmed with the interviews. Neonates in particular, desired recognition and appreciation for their efforts to be positive role models to the students. Experienced teachers who taught grade 12 students needed recognition if results were acceptable, in particular in the light of parental apathy or a poor teaching and learning culture. In this regard, one teacher stated: 
One would normally strive for a culture of teaching and learning at school, but this is non-existent at my school... and yet learners expect to pass. I summarise to say it is a sunshine culture where learners just like to be outside doing nothing and expect to pass. (IM)

To improve motivation, teachers recommended that they be praised for good work in addition to being rewarded appropriately, including receiving remuneration for work done after hours.

\subsubsection{Social support and supervisory coaching}

Teachers' views of the supervision and the social support at school are illustrated in Table 4.

Table 4: $\quad$ Perceptions of supervision teachers received and the social support at school

\begin{tabular}{|l|c|c|c|}
\hline \multicolumn{1}{|c|}{ Item } & $\begin{array}{c}\text { Disagree } \\
\%\end{array}$ & $\begin{array}{c}\text { Neutral } \\
\%\end{array}$ & $\begin{array}{c}\text { Agree } \\
\%\end{array}$ \\
\hline $\begin{array}{l}\text { Departmental heads support teachers to excel in the } \\
\text { classroom }\end{array}$ & 32 & 39 & 29 \\
\hline $\begin{array}{l}\text { The SMT and staff of my school enjoy a good } \\
\text { working relationship. }\end{array}$ & 30 & 29 & 41 \\
\hline $\begin{array}{l}\text { The SMT deal with conflict resolution in a } \\
\text { professional manner in my school. }\end{array}$ & 33 & 29 & 38 \\
\hline $\begin{array}{l}\text { My principal encourages open communication. } \\
\text { Teachers at my school support one another in the } \\
\text { realisation of educational outcomes. }\end{array}$ & 26 & 28 & 53 \\
\hline $\begin{array}{l}\text { Collegial support raises motivation and job } \\
\text { satisfaction of teachers at my school. }\end{array}$ & 22 & 36 & 42 \\
\hline $\begin{array}{l}\text { Harmonious superior-subordinate relations ensure } \\
\text { the smooth functioning of my school. }\end{array}$ & 22 & 35 & 42 \\
\hline $\begin{array}{l}\text { Managers at my school engage teachers in } \\
\text { participatory decision-making. }\end{array}$ & 36 & 26 & 38 \\
\hline $\begin{array}{l}\text { My school principal sets a good example of a fair } \\
\text { leader. }\end{array}$ & 40 & 27 & 32 \\
\hline $\begin{array}{l}\text { The SMT motivates teachers at my school to } \\
\text { perform well. }\end{array}$ & 28 & 38 & 34 \\
\hline $\begin{array}{l}\text { Students and teachers enjoy decent working relations } \\
\text { at my school. }\end{array}$ & 28 & 31 & 41 \\
\hline $\begin{array}{l}\text { Uncooperative students are held accountable for their } \\
\text { actions at my school. }\end{array}$ & 37 & 25 & 37 \\
\hline The RCL works closely with teachers at my school. & 42 & 25 & 33 \\
\hline $\begin{array}{l}\text { The local community provides support services to } \\
\text { students at my school. }\end{array}$ & 66 & 27 \\
\hline $\begin{array}{l}\text { Parents of students at my school supervise students' } \\
\text { work. }\end{array}$ & 67 & 36 \\
\hline $\begin{array}{l}\text { The school management ensures that there are } \\
\text { effective teacher-parent partnerships at my school. }\end{array}$ & 36 & 29 \\
\hline $\begin{array}{l}\text { Departmental heads support teachers to excel in the } \\
\text { classroom. }\end{array}$ & 32 & 26 \\
\hline
\end{tabular}


Table 4 shows that the greatest level of discontent was with lack of support from parents and the local community (indicated by $67 \%$ and 66\%). The highest positive response (46\%) was for the support of teachers for one another to achieve educational aims; $42 \%$ of the teachers agreed that collegial support and relations improved their motivation and ensured the smooth running of the schools. For most of the positive statements on social support and coaching, respondents were about equally divided between 'disagree', 'neutral' and 'agree'.

When tested for significant differences between groups, t-test analysis revealed that male teachers were significantly more satisfied (on the 5\%-level) with their interpersonal relationships than females (means: male $=09350$; female $=1,91906$; std error $=0,10306$; significance $=0,0469$ ).

In response to the open-ended questions, teachers were critical of ineffective leadership at school. This was related to principals and the SGB, in particular. Examples are:

The application of Affirmative Action policies resulting in the promotion of inefficient and ineffective candidates, coupled with the lack of commitment, guidance and monitoring by the principal is very demotivating. (IM)

My personal view on the SGB's influence on the school is very negative. Our SGB's aim is not to build the school. Their biggest aim... is how money is spent, and how are tenders being issued. So I don't think they are very beneficial to my school. (BM)

\subsection{Job demands}

The job demands that were investigated included work pressure and work load, as well as emotional and mental demands of the various roles that the teachers were required to play. Perceptions are illustrated in Table 5.

Table 5:

Perceptions of job demands

\begin{tabular}{|l|c|c|c|}
\hline \multicolumn{1}{|c|}{ Item } & $\begin{array}{c}\text { Disagree } \\
\%\end{array}$ & $\begin{array}{c}\text { Neutral } \\
\%\end{array}$ & $\begin{array}{c}\text { Agree } \\
\%\end{array}$ \\
\hline Teachers at my school are happy with their workload. & 48 & 26 & 26 \\
\hline $\begin{array}{l}\text { The negotiated 1:32 teacher-student ratio is adhered to } \\
\text { at my school. }\end{array}$ & 75 & 15 & 9 \\
\hline Students from larger classes perform well at my school. & 73 & 21 & 5 \\
\hline $\begin{array}{l}\text { In my school teachers perform several roles in addition } \\
\text { to classroom teaching (such as care givers, social } \\
\text { workers or counsellors). }\end{array}$ & 11 & 17 & 72 \\
\hline $\begin{array}{l}\text { Teachers at my school are able to work well under } \\
\text { pressure. }\end{array}$ & 23 & 21 & 55 \\
\hline $\begin{array}{l}\text { I agree that students with special educational needs are } \\
\text { placed in the same class as the others }\end{array}$ & 65 & 14 & 21 \\
\hline $\begin{array}{l}\text { Teachers at my school easily handle students with } \\
\text { special educational needs. }\end{array}$ & 51 & 30 & 19 \\
\hline $\begin{array}{l}\text { I agree with the fact that older students are placed in } \\
\text { the same classes as the normal age cohort group of } \\
\text { students. }\end{array}$ & 56 & 15 & 29 \\
\hline Student violence seldom occurs at my school. & 29 & 22 & 49 \\
\hline
\end{tabular}




\begin{tabular}{|l|c|c|c|}
\hline $\begin{array}{l}\text { Traumatisation because of intimidation is absent at my } \\
\text { school. }\end{array}$ & 35 & 27 & 38 \\
\hline Drug abuse is not a problem at my school & 61 & 20 & 19 \\
\hline $\begin{array}{l}\text { Teachers are well-prepared to deal with problems of } \\
\text { substance abuse at my school. }\end{array}$ & 49 & 24 & 26 \\
\hline $\begin{array}{l}\text { Teachers are well-prepared to deal with criminality at } \\
\text { my school. }\end{array}$ & 60 & 18 & 22 \\
\hline $\begin{array}{l}\text { Teachers are satisfied with the abolishment of corporal } \\
\text { punishment at my school. }\end{array}$ & 59 & 31 & 10 \\
\hline $\begin{array}{l}\text { Safety measures at my school contribute to the smooth } \\
\text { running of my school. }\end{array}$ & 37 & 27 & 35 \\
\hline $\begin{array}{l}\text { Teachers at my school are happy with the assessment } \\
\text { policies of the DoE. }\end{array}$ & 43 & 27 & 30 \\
\hline $\begin{array}{l}\text { IQMS as an evaluation tool for teachers is well-received } \\
\text { by teachers at my school. }\end{array}$ & 53 & 24 & 54 \\
\hline $\begin{array}{l}\text { IQMS is carried out in a transparent manner in my } \\
\text { school. }\end{array}$ & 22 & 33 & 26 \\
\hline $\begin{array}{l}\text { IQMS has empowered me to improve my teaching } \\
\text { practice in the classroom. }\end{array}$ & 40 & 22 & 42 \\
\hline My students are generally well-disciplined. & 32 & 43 \\
\hline The ethos in my school is good. & 36 & 37 \\
\hline $\begin{array}{l}\text { The schools medium of instruction supports student } \\
\text { performance at my school. }\end{array}$ & 32 & 28 \\
\hline
\end{tabular}

The job demands of the teaching profession emerged as one of the most important aspects of the teachers' work that could inhibit work engagement. Table 5 indicates the following as most significant: large classes and unsatisfactory teacher-student ratios that were demanding; handling students with special educational needs or older students in the same classes as the others; and challenges related to substance abuse and criminal activity; $59 \%$ of the teachers were also unhappy that they could not use corporal punishment to discipline students. Regarding IQMS, more than half of the group (53\%) did not think it was well received by teachers as an evaluation tool.

T-tests found significant differences between Black and Indian teachers with regard to their perceptions of the nature of their job. Black teachers were significantly more satisfied with the demands of the job (on the 1\% level) than their Indian counterparts: (means: African = 2,01218; Indian = 1,79402; Std error =0,07832; Significance $=0,0064$ ).

In the open-ended questions some teachers mentioned factors that improved their work engagement, such as working with the learners. For example:

Empowering students to reach out and take that opportunity to be the best individuals

they can be academically, in sport and in society is motivational. (IF)

Several teachers expressed dissatisfaction with the Outcomes Based Education (OBE) system and the significant work associated with its administration and with assessment. In addition to $\mathrm{OBE}$, the teachers referred to the students and their parents as follows: 
Professional parents, lawyers, politicians who think they know a lot and want to dictate to teachers, is very demotivational. (IM)

[It is also demotivational] when parents complain about teaching and teachers... since some of them know very little about what goes on in school. Also parents' attitudes when they are informed about their kids' poor discipline. (AM)

IQMS as an evaluative instrument for teachers was also not well received and the interviews illustrated that the teachers viewed it as a perfunctory exercise only. They noted that it disregarded the contextual realities of schools. Although the neonates to the profession in relatively newly built schools tended to find the IQMS quite valuable, most of the other teachers were unhappy. They did not believe that it developed them in any way. For example:

\begin{abstract}
When one looks at the IQMS, it ought to be a developing instrument and there is a rating. There is no national procedure or district-wise way to moderate the scores. You would find a teacher in a certain area scoring 100, and a better teacher in another area scoring 86 or even lower. So it really is not a proper instrument in assessing teachers. There is no fairness, but many challenges with the IQMS. (BF)
\end{abstract}

Mention was also made of stressful routines with hardly have any free time during the day. In between teaching there was administrative work to attend to such as the collection of school fees. Another teacher referred to how demanding it was to teach a subject such as English when the majority of the students were second language students with low competence levels of English.

\title{
6.3 The consequences of a lack of work engagement
}

The consequences of a lack of work engagement were apparent during the interviews. Inter alia teachers referred to the wish for early retirement or resignation; frequent absenteeism largely due to stress, depression, and/or ill-health; poor engagement in the classroom resulting in poor performance of students; and frustrations resulting in conflicts with the SMT. The following quote serves as an example:

Demotivation suppresses the teachers' ability to perform in class. Teachers feel
demoralised. They don't involve themselves in school activities. They merely go through
the motions in class. They have no urgency, no punctuality, but become ineffective in
class, and students lose out on the expertise of teachers. (IM)

\subsection{Discussion of results}

The results show that the work engagement of the secondary school teachers in the rural district of Illembe was poor as illustrated by expressed wishes for early retirement or resignation, frequent absenteeism, depression and frustration which resulted in conflict with management. These psychological costs were related to poor job resources which could not buffer the negative impact of high job demands. Although all items in the questionnaire were formulated positively, in only three instances just over $50 \%$ of the teachers agreed with the statements. This revealed negative attitudes and dissatisfaction. Interviews confirmed a lack of passion and dedication to teaching.

Job resources fulfil a basic need for competence (Bakker \& Demerouti 2008:212). A study with Finnish teachers revealed that the job resources they needed to enhance their work engagement were related to job control, information, and an innovative climate, among 
others (Bakker \& Demerouti 2008:212). In this study, the resources required were more basic but vital for good teaching - yet they were absent or were not delivered on time. Since most families in the area were poor, resources could not be obtained through this channel. The most significant source of discontent of the teachers, however, was with their remuneration packages. The teachers that were most satisfied with resources and salaries were those with 26 years and more experience, or who were well-qualified. This seems understandable in view of the fact that they earned more than the less experienced/qualified group. Regarding satisfaction or not with the availability of modern technology, older (more experienced) teachers are often set in their ways and not as motivated as younger teachers to employ modern technologies and would therefore be less frustrated by their absence.

Dissatisfaction with salaries was aggravated by the fact that many of the teachers felt unappreciated. Although nearly half of them were pleased about the DoE's laptop initiative; other strategies of reward failed to impress them. Thus the DoE was out of step with the needs of the teachers.

Interview data also revealed that school buildings and grounds were neglected. This was symptomatic of low work engagement of the SMT that impacted on that of the staff and on their performance.

Poverty in the community related to low educational levels, facilitated parental uninvolvement in school matters. For the teachers, this was somewhat balanced with the support colleagues gave one another to ensure the functioning of the schools. However, it was clear that the support of the school SMT did little to motivate teachers and improve their work engagement. A lack of social support was particularly important to female teachers. This may be explained by greater social dependencies of females in general, or by being more motivated than the males to achieve work-related goals through the necessary support.

Job resources are pivotal for work engagement and their motivational influence is most important when job demands are high. In this study, job demands played a significant role to counteract work engagement. Table 5 and the qualitative data illustrate that the demands of large classes and unsatisfactory teacher-student ratios; the presence of students with special educational needs or older students in the same classes as the others; and the challenges posed by learners with substance-abuse and behavioural problems were important issues that inhibited their work engagement.

Finally, the IQMS was not well received as a fair evaluation tool by many of the teachers, in particular by the Indian teachers. This may have been influenced by the complex interplay of political factors with job demands. The job demands of rural schools (e.g. related to large classes) were also more familiar to the Black teachers since many of them came from similar educational backgrounds. Thus, the Black teachers revealed less dissatisfaction with job demands.

Although this study revealed the particular factors that currently influenced the work engagement of teachers in rural KwaZulu-Natal, these factors are not new. Previous authors have identified similar factors that impacted on job satisfaction and motivation of teachers in other areas (Kallaway 2007:30; Maniram 2007:4; Roper 2007:10). The implication is that teachers were not heard, and that it was business as usual in spite of recommendations to managers for improvement. 


\section{Conclusions}

The study aimed to determine how job resources and job demands impacted on the work engagement of secondary school teachers in the Ilembe District of KwaZulu-Natal. Instead of experiencing positive, fulfilling, work-related states of mind, the teachers were generally demotivated and revealed low levels of work engagement. This was related to an absence of effective job resources as drivers of work engagement. Although personal resources could influence work engagement, this was not the focus of the study since personal resources are difficult to change.

In the Illembe district of KwaZulu-Natal, the most important job resources that were needed included: smaller classes; the timely delivery of relevant educational resources; better remuneration packages, and improved evaluation, recognition and rewards of teachers (which requires effective communication between the DoE and teachers); improved maintenance of buildings and school grounds (through greater SMT efforts); improved parental involvement (by the SMT); more teacher support and coaching (by the SMT); and professional development of teachers related to the handling of students with special needs or behaviour problems (organised by the SMT and the DoE).

The above-mentioned indicates areas of intervention. It also shows the importance of contextualised professional development programmes. When such programmes are carried out, the above-mentioned issues could be raised and teased out. This would present opportunities for improved communication between the DoE, the SMT and the teachers. Ultimately, the job resources of teachers could be improved and the demands of their work reduced. This could facilitate improved work engagement displayed as dedication and enthusiasm.

Although this study was limited to one rural area in KwaZulu-Natal, the contexts are similar to those of other rural areas. This enhances the significance of this study to understand the effects of job demands and resources on the work engagement and performance of teachers in rural South Africa.

Follow-up studies with other groups of teachers in affluent contexts are needed. Such examples may give direction to innovative ways to improve work engagement. Engaged teachers employ themselves physically, cognitively and emotionally in the performance of their roles to the benefit of their students. They show energy, enthusiasm and dedication to teach and to learn and thus facilitate positive personal and educational outcomes.

\section{References}

ATKINSON ES. 2000. An investigation into the relationship between teacher motivation and pupil motivation. Educational Psychology, 20(1):45-47.

BAKKER AB \& DEMEROUTI E. 2008. Towards a model of work engagement. Career Development International, 13(3):209-223.

BAKKER AB \& SCHAUFELI WB. 2008. Positive organizational behaviour: engaged employees in flourishing organizations. Journal of Organizational Behavior, 29:174154. 
BEZUIDENHOUT A, \& CILLIERS FVN. 2010. Burnout, work engagement and sense of coherence in female academics in higher-education institutions in South Africa. $S A$ Journal of Industrial Psychology/SA Tydskrif vir Bedryfsielkunde, 36(1):872-883.

BLOCH G. 2010. Education a tried and tested route out of poverty. The Mercury, April $26: 1$.

BUYS C \& ROTHMANN S. 2010. Burnout and engagement of reformed church ministers. SA Journal of Industrial Psychology/SA Tydskrif vir Bedryfsielkunde, 36(1):825-836.

COHEN L. 2009. Schooling a national disaster. The Times, 16 September: 7.

CRESSWELL JW. 2003. Research design: qualitative and mixed-method approaches. Thousand Oaks, California: Sage Publications Inc.

DAVIDS N \& MAKWABE B. 2007. Teachers can't take it any more. Sunday Times, 9 September: 1.

DE CLERQF. 2008. Teacher quality, appraisal and development: the flaws in the IQMS. Perspectives in Education, 26(1):7-18.

DEHALOO G. 2008. The appointment process of education managers and its consequences for schools. Unpublished M. Ed. dissertation. Pretoria: University of South Africa.

DEPARTMENT OF PUBLIC SERVICE AND ADMINISTRATION. 2009. Salaries and Benefits in the Public Service. Pretoria: Government Printer.

DEVELOPMENT BANK OF SOUTH AFRICA. 2008. Education Roadmap. Focus on the schooling system. DBSA Roadmap Process. November 2008.

EDUCATION AND LABOUR RELATIONS COUNCIL. 2003. Policy handbook for educators. Durban: Universal Print Group.

EVANS RI. 1989. Albert Bandura: The man and his ideas - a dialogue. New York: Praeger

GALLIE M. 2006. The implementation of the development appraisal in a low functioning South African school. Unpublished Ph.D. thesis. Pretoria: University of Pretoria.

GUTTMAN C. 2007. Defining quality and inequality in education. Education South Africa. Life Long Learning, 1(5):14-15.

KALLAWAY P. 2007. The profound crisis of teaching. [Internet: Mail E Guardian http://mg.co.za/article/2007-08-21-the-profound-cirsis-of-teaching; downloaded on 2012-03-7.]

KARP S. 2007. Beyond the classroom - deep reforms including broader policy struggles. Education South Africa. Life Long Learning, 1(5):5.

KELEHEAR Z. 2004. Controlling stress. Principal Leadership, 5(3): 30-33.

KHAN J, MFUSI N \& GASA S. 2010. KZN's unskilled teachers. The Mercury, 20 July:1.

KYRIACOU C. 2001. Teacher stress: direction for future research. Educational Review, 53: 27-35.

MANIRAM R. 2007. An investigation into the factors affecting job satisfaction at the KwaZulu Natal Further Education and Training College - Swinton Campus. Unpublished M.Ed. dissertation. Pretoria: University of South Africa. 
MARAIS P \& MEIER C. 2010. Disruptive behaviour in the foundation phase of schooling. South African Journal of Education, Vol. 30, pp.41-57.

MCMILLAN JH \& SCHUMACHER S. 2010 Research in education: evidence-based inquiry. ( $7^{\text {th }}$ Edition). Boston:Pearson.

MOHLALA T. 2010. Principals key to performance. The Teacher, October 2: 1.

MOKHELE PR. 2006. The teacher-learner relationship in the management of discipline in public high schools. Africa Education Review, 3(1\& 2):148-159.

OLOLUBE NP. 2006. Teachers' job satisfaction and motivation for school effectiveness: an assessment. Essays in Education. Helsinki: University of Helsinki.

PANDAY S \& ARENDS F. 2008. Not going all the way. The Teacher, 13(2):22.

PHURUTSE MC. 2005. Factors affecting teaching and learning in South African Public Schools. Report presented to the Education Labour Relations Council by a research consortium comprising the Human Sciences Research Council and the Medical Research Council of South Africa. Cape Town: HSRC Press.

POWELL A, BORDOLOI B \& RYAN SD. 2007. Data flow skills acquisition: Impact of cooperative versus individual learning. Journal of Information systems Education, 18(1):103-12.

REPUBLIC OF SOUTH AFRICA. 2000. Norms and standards for education. National Education Policy Act 1996. Government Gazette, 415: 20844. Cape Town: Government Printer.

ROPER M. 2007. School Safety - turning the tide! Education Southern Africa. Life Long Learning, 5:20-21.

ROTHMAN S \& STORM K. 2003. "Work engagement in the South African Police Service", paper presented at the $111^{\text {th }}$ European Congress of Work and Organizational Psychology, 14-17 May 2003, Lisbon.

SAMUEL M. 2007. School safety - turning the tide. Education South Africa. Life Long Learning, 1(9):10-11.

SCHULZE S \& STEYN GM. 2007. Stressors in the professional lives of South African secondary school educators. South African Journal of Education, 27:691-707.

SERRAO A. 2010. Trillion-rand education scandal. The Mercury, February 22:4.

STANDER MW \& ROTHMANN S. 2010. Psychological empowerment, job insecurity and employee engagement. South African Journal of Industrial Psychology, 36(1):849857.

STEYN GM. 2002. A theoretical analysis of educator motivation and morale. Educare, 31 (1 \& 2):82-101.

WEBER E. 2005. New controls and accountability for South African teachers and schools: the Integrated Quality Management System. Perspectives in Education, 23(2):63-72. 